\title{
The Development of a Metacognition Instrument for College Students to Solve Physics Problems
}

\section{Haeruddin}

Student of Postgraduate Program, Yogyakarta State University, Indonesia, haeruddin.spd2015@student.uny.ac.id

\section{Zuhdan Kun Prasetyo}

Prof., Master of Science Education, Yogyakarta State University, Indonesia, zuhdan@uny.ac.id

\section{Supahar}

Master of Science Education, Yogyakarta State University, Indonesia, supahar@uny.ac.id

\begin{abstract}
This study aims at developing an instrument to measure metacognition in solving physics problems among college students. This study used Research and Development (R \& D) model with the non-test instrument development model. The instrument was in the form of a questionnaire that consisted of four choices with the scale was ranging from 1 to 4 . There were 664 first-year college students participating in this study which were chosen with purposive sampling technique. They had taken a basic physics course at Tadulako University. Before completing the questionnaire, the students were asked to solve the two physics problems. The expert judgment conclusions were analyzed by means of Aiken formula. The empirical data analysis employed the Quest program to test the Goodness of Fit (GoF) to Partial credit model (PCM) and item validity, while the instrument reliability and the analysis factors for the validity of the metacognition dimension in solving physics problems were tested with the assistance of the SPSS program. The results of the content validity with the Aiken's V value was .81 and the reliability was .90 , and the mean of INFIT MNSQ 1.00 with a standard deviation of .18 respectively. It was identified that eight factors of metacognition that contributed to solve physics problems, such as declarative knowledge, procedural knowledge, conditional knowledge, planning, monitoring, evaluation, debugging and information management. These results can be used as the guidelines to measure students' metacognitive abilities in solving physics problems.
\end{abstract}

Keywords: metacognition factors, physics problem solving, college students, physics, measure metacognition

Citation: Haeruddin, Prasetyo, Z. K., \& Supahar. (2020). The Development of a Metacognition Instrument for College Students to Solve Physics Problems. International Journal of Instruction, 13(1), 767-782. https://doi.org/10.29333/iji.2020.13149a 


\section{INTRODUCTION}

Problem solving is generally regarded as a concept of complex cognition, and it is listed as a basic part of science learning. When students attempt to solve physics problems, they will be through the complex cognitive processes. Several studies are trying to reveal the variables of problem solving by examining the strategies of physics problem solving between experts and beginners (Kohl \& Finkelstein, 2008), physics problems with different contexts (Ibrahim \& Rebello, 2013; De Cock, 2012), and the processes of microstructure in solving physics problems (Hegde \& Meera, 2012). This research focuses on one of the metacognitive processes carried out by students in solving physics problems since they are the center of the learning process.

The role of metacognition in the problem-solving process is inseparable from the students' thinking process. As mentioned by Kryjevskaia et al. (2014) that the higher metacognition the better reasoning will students have since it serves to regulate the interaction between intuitive and analytical reasoning. Koch (2001) also states that students who have metacognition is more likely to have adequate problem solving skills in physics. It means revealing students' metacognition will be beneficial to enhance science learning, especially to improve students' problem-solving ability.

The role of metacognition ability for the students' learning outcomes including the aspects of cognitive, affective, and psychomotor processes (Srinivasan \& Pushpam, 2016). Metacognition can enhance conceptual understanding of science (Colthorpe et al., 2018), develop students' higher-order thinking skills (Ghanizadeh, 2017), and improve their attitude towards science in order to improve the students' learning outcomes in science (Jahangard et al., 2016). Metacognition has been the determining factor for students' success in solving problems (Balta et al., 2016). Until now, the term metacognition has been included in the current Educational system of Indonesia, the 2013 curriculum.

Since Flavell (1979) revealed the concept of metacognition, many researchers have reported the results of metacognition assessment. For example, metacognition cannot be observed directly on students because its process occurs internally (Sperling et al., 2002). One way to assess metacognition is by inviting the subjects to report the strategies when performing various tasks. Balta et al. (2016) examine the metacognition among students' attitudes and approaches in solving physics problems. They obtain ten factors and find that metacognition is the biggest factor in solving physics problems.

Another study also conducted on the metacognition process that occurs when students complete physics problem solving (Taasoobshirazi \& Farley, 2013; Taasoobshirazi et al., 2015; Abdullah, 2006). Taasoobshirazi uses quantitative methods with self-report as the research instrument, while Abdullah employs qualitative techniques with in-depth interviews. The instrument developed by Taasoobshirazi consisted of 24 statements focusing on the use of diagrams that confirmed six factors. What is done by Taasoobshirazi and Farley (2013) is received some suggestions to add the number of items in the debugging factor. The additional items to these factors is to enlarge the indicators of metacognitive awareness. 
It means the efforts to include metacognitive thinking in the process of physics problems solving are very important to reveal students' metacognitive awareness. The students indeed can obtain metacognitive theories, yet the practice of problem-solving process is truly needed to obtain the skills (Zohar \& Barzilai, 2013). Therefore, it is important to know the level of students' metacognition that they already have before developing their metacognition. In this case, the proper and standard instrument is crucial to produce the accurate metacognition level among the students.

Based on the problems described above, the purpose of this study is to design the metacognition instrument in solving physics problems among college students. It is done by measuring students' metacognition skills with the valid and reliable questionnaire instrument. The metacognition instrument in solving physics problems need to be developed as the teacher's guideline to gain meaningful feedbacks during the problemsolving process. Through these feedbacks, students can maintain the proper practice for developing their metacognition aspects that are still low, and strengthen what they have already good at. This metacognition questionnaire was created to measure skills and gain insight about students' metacognition when solving physics problems.

\section{REVIEW OF LITERATURE}

\section{Solving Physics Problems}

Resolving problems is an integral part of students' thinking process which also involves reasoning. The use of problem-solving strategies will be different if they faced a similar problem with the different context (Ivanjek et.al., 2016). Students in solving problems require the transfer of knowledge using the techniques and strategies in physics. Several variables in solving physics problems were identified based on the results of qualitative research by Walsh et al. (2007), who find that a hierarchical approach to problemsolving consists of four main categories: scientific, plug-and-chug, and memory-based approaches, and no clear approach.

In the initial observations conducted by the researchers during the basic physics courses at Tadulako University, it was found that most of the students could not solve the problem correctly. The majority of the students were only able to solve problems, if the problem was similar to the given example. When the context was changed, they found it difficult to solve it. This condition is similar to Ibrahim and Rebello (2013) findings that students tend to choose strategies related to their knowledge level, form of problem representation and its familiarity with the topic of the problem. It indicates that the students only memorize the examples and did not understand the problem-solving process. In line with this, Mundilarto (2003) highlights that the level of students' understanding of physics is still low that can be seen by the number of errors both in writing and understanding the formulas as well as the physics concepts.

\section{Metacognition Theories}

Flavell (1976) defines metacognition by referring to two categories, namely knowledge and self-monitoring. Metacognition that refers to knowledge is one's knowledge of a person's cognitive processes and products or anything related to them. This knowledge 
is related to information about the relevant data to learning. Meanwhile, metacognition on monitoring has a result of regulation and process of the instrument in relation to cognitive objects or the used data. It is supported by Chekwa et al. (2015) that explain metacognition as an awareness of one's learning or rational processes. It gives an appreciation of existing knowledge and give space for a new knowledge. Someone who has learned a certain strategy in the particular context can use it to gain another strategy that is closely related for another context.

Several metacognitions are associated with Multiple Contexts Inventory (Allen \& Armour-Thomas, 1993), Motivated Strategies for Learning Questioner (Pintrich et al., 1993), Metacognitive Awareness Inventory (Schraw \& Dennison, 1994) and Awareness for Independent Learning Inventory (Meijer et al., 2013). Moreover, Garrison and Akyol (2015) validated the development of metacognition to understand the structure and dynamics of metacognition in inquiry collaborative learning environments.

Metacognition is a person's knowledge, awareness, and control of the processes and results for his/her thinking. In general, metacognition has two constituent parts: knowledge of cognition and monitoring or regulation of cognition (Flavell, 1979; Schraw et al., 2006; Alexander, 2008; Dinsmore et al., 2008; Wall, 2008; Veenman et al., 2006). The development of metacognition concept does not only consist of two main components. Meijer et al. (2013) divide metacognition concept into three components, namely (1) metacognitive knowledge, such as (a) knowledge of people, (b) knowledge of strategies, and (c) knowledge of assignments, (2) metacognitive arrangements, namely (a) orientation to personal functions in a learning process, (b) monitoring the implementation of the learning process, and (c) evaluating personal functions in a learning process and (3) metacognitive responses including (a) sensitivity to metacognitive experiences (internal feedback during learning process), (b) sensitivity to external feedback on personal cognitive function, and (c) curiosity regarding personal cognitive function and its development.

Furthermore, Akyol and Garrison (2011) divide metacognition into three dimensions: 1) knowledge of cognition, as a metacognitive state that reflects the knowledge and motivation that related to the investigation process; 2) monitoring cognition, as a reflection of actions that related to the learning assessment process; and, 3) regulation of cognition as a control of the learning process (reflection in action) that requires effort to achieve meaningful learning outcomes. Meanwhile, metacognition related to physics problem solving was carried out by Taasoobshirazi and Farley (2013). The results of the study based on exploratory factor analysis reveal six components of student metacognition when solving physics problems, such as: (1) knowledge of cognition, (2) planning, (3) monitoring, (4) evaluation, (5) debugging, and (6) information management.

\section{METHOD}

\section{Type of Research}

This study used a non-test instrument development model containing 10 steps (Mardapi, 2012): (1) determining instrument specifications, (2) writing instrument, (3) determining 
instrument scale, (4) determining scoring system, (5) analyzing instrument, (6) conducting trials, (7) analyzing instrument, (8) arranging instrument, (9) conducting measurements, and (10) interpreting the measurement results.

\section{Development Procedure}

The development step begins with the literature study to determine and define metacognitive variables when solving physics problems. Based on the variable definition, it was determined the metacognition indicators and created the constructs guidelines, questions and answer formats, and scoring methods. The scale was the scale of the tendency on each individual to control the thinking process. Therefore, the appropriate test format was a questionnaire with the scale of $1-4$. The test items was referring the indicators of each variable to be measured and elaborated in the question items.

The next step was reviewing the test items from an expert of measurement and educational psychology, and five experts of physics education. After that, some improvements were made based on the results of the expert judgments. The revised instrument was then tested to 15 college students in the second-year of physics education to clarify its readability aspect. The test was carried out to the students who joined the basic physics course at Tadulako University. This step aimed to provide empirical data to analyze the quality of the test items, the reliability and the validity of the test.

After that, the development phase was started by reviewing the test items according to physics education experts as well as an educational psychology expert and some improvements were made. The revised instrument was tested in the limited trial among the first-year students who joined the basic physics courses at Tadulako University in order to gain the empirical data to analyze the quality of the test items as well as the reliability and the validity of the test. The item determination whether it was good or not used the criteria of quantitative item analysis. The fulfilled items used in the implementation phase are presented in Figure 1.

\section{Respondents}

The research respondents were selected with purposive sampling technique with the criteria of the students who attended the basic physics course. The trial group was the second-year students in the Physics Education Study Program and the main study group was the first-year students from several science faculties. The total of 15 students (10 women, 5 men) participated in the trial and 664 students (423 women, 124 men) aged 17-19 years old in the main study.

Before students responded the metacognition questionnaire, they were asked to complete the physics exercise to recall their thinking processes that they had ever done. The main study was conducted among Tadulako University students who had joined the Basic Physics course in several science faculties. The respondents involved in the study were 713 students and after the questionnaire was collected, 664 questionnaires passed the requirements for analysis. Since some questionnaire had incomplete answers and 
some items contained the exactly same answer for all items which were cannot be guaranteed for its originality.

\section{Instrument of Data Collection}

The instrument used to collect data consisted of two, physics questions and instrument of metacognition in solving physics problems. The question of physics on kinematics topics included 2 items with the format of verbal representation and graphics. The researcher made a question with modifications that already existed in the book, so that the test conducted was readability by physics education experts. The questions were to make the respondents easier to recall their thinking process they had already done. The instrument of metacognition in solving physics problems is the main instrument of this study.

\section{The Measurement Scale and Scoring system}

The measurement scale of the questionnaire items was arranged using 4-point Likert scale: 1 = never, 2 = rarely, 3 = often, 4 = always. "Never" means do not have or never carry out activities as mentioned. "Rarely" refers to ever do, but for a long time ago, only1 or 2 times in solving physics problems. "Often" indicates doing it for several times like 3 to 4 times in solving physics problems. "Always" was having the solving physics problems continuously. For the negative statements, the judgment was made otherwise.

\section{Data Analysis}

Expert judgment was carried out by 7 experts consisting of 5 physics learning practitioners, 1 cognitive psychologist, and 1 measurement expert. The data analysis was through expert judgement with Aiken formula with the criteria if the index was less than or equal to .40 , it can be considered that the validity was low, $.40-.80$ categorized as is moderate, and if bigger than .80 was listed as very valid (Retnawati, 2016). 


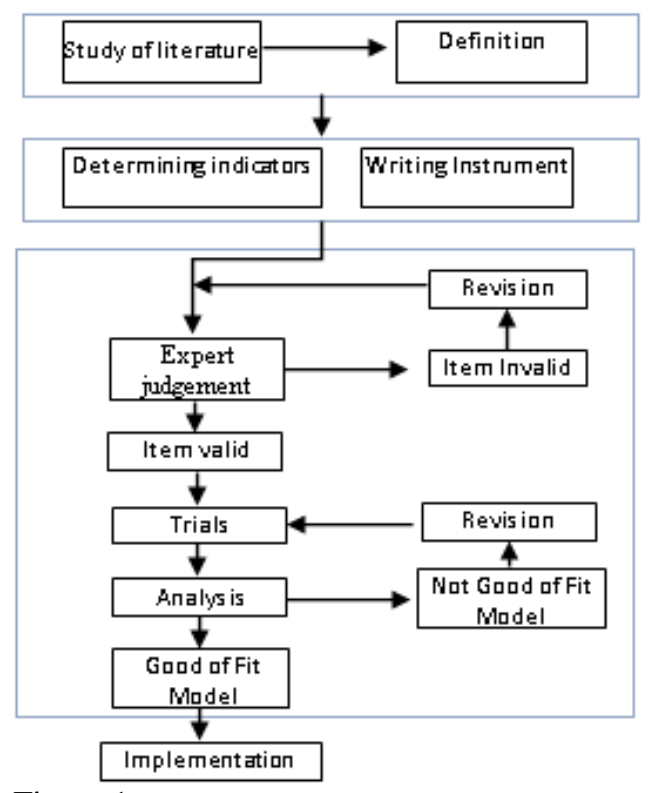

Figure 1

Chart of Developed Instrument Model

The empirical data analysis was using the Quest and SPSS programs. The Quest program was used to verify the suitability between the model and the difficulty level of the index, while the SPSS was to reveal the Exploration Factor Analysis (EFA). The data analysis included several aspects, namely: a) Goodness of Fit (GoF) to Partial Credit Models (PCM), b) item validity, c) instrument reliability, and d) exploratory factor analysis.

GoF to PCM referred to the fit-test on the overall test that was based on the average and the standard deviation of INFIT Mean Square (MNSQ). If the average value of INFIT MNSQ approached 1.00 and the standard deviation was close to .00 , then the overall item fitted in the PCM One-Parameter Logistic (1 PL) model. All of these analyses can be done with the help of the QUEST program.

According to Adams and Khoo (1996), the item validity that were considered fit if the INFIT MNSQ value was in the range between 0.77 and 1.30 . The item can be considered in good condition or worthy of use.

The reliability covered the estimated reliability of the instrument that can be reviewed based on the output analysis using SPSS at the value of Cronbach's Alpha. According to Mardapi (2012), this instrument was quite good if it had the reliability coefficient or reliability index equal to or bigger than .70 .

The EFA aimed at determining the factors that construct metacognition when solving physics problems. This analysis used the SPSS version in 25.00. In EFA, Chi-square at 
the Barlette Test showed the adequacy of the sample. If the significance value was less than .01 , then the sample was said to be sufficient or fulfilling. The results were reinforced by KMO MSA values that was bigger than .50 (Hair et al., 2010).

\section{FINDINGS AND DISCUSSION}

\section{Components of Metacognition in Solving Physics Problems}

Based on the literature study above, the component of metacognition in the study consisted of two parts, namely metacognitive knowledge and metacognitive arrangements. The metacognitive knowledge referred to knowledge awareness possessed by someone that influence their cognitive strengths and limitations in solving physics problems. On the other hand, the metacognitive monitoring was an action that helps college students to plan, implement, monitor misunderstandings, and evaluate their problem-solving.

The first component was metacognitive knowledge consisting of three types of knowledge, namely declarative, procedural, and conditional knowledge. The declarative knowledge discussed the students' awareness of knowledge when solving physics problems. The procedural knowledge was the knowledge about how to do a task or activity to solve the physics problems. Meanwhile, the conditional knowledge represented the knowledge about the time and the reasons to use declarative and procedural knowledge.

The second component of metacognition was the metacognitive monitoring consisting of planning, monitoring, evaluation, debugging and information management. The planning was the ability to plan physics problem-solving activities. The monitoring implied the ability to monitor the problem-solving process of physics and things related to the process. The evaluation was the ability to evaluate the effectiveness of the strategies used in solving physics problems, to change his/her strategy, to give up to the situation, or to end the activity. The debugging explained the ability that was used to correct the wrong actions when completing physics problems. The information management is the ability to manage information regarding the problem-solving process that was done.

To describe the metacognitive behaviour when performing the problem-solving process was very complicated because the process occurred internally. So, it was is necessary to develop the indicators that can be observed externally. This indicator was the framework to uncover the metacognition data when solving physics problems.

\section{Test Results}

The assessment result towards the items quality based on the indicators from the expert judgment obtained .81 which means very valid. Some improvements based on expert suggestions were including the use of appropriate words such as "removing information" was replaced by "ignoring information".

\section{The Goodness Fit for the Instrument Item of Metacognition in Solving Physics Problems}

The compatibility test criteria were if the average value of INFIT MNSQ was close to 1.00 and the standard deviation was close to .00 , then the overall item was considered 
suitable for the PCM model. Based on the results of data analysis, the characteristics of metacognition instrument in solving physics problems were 43 items for 664 students (male $=241$ and female $=423$ ) with the probability level of .50 and using PCM 1 PL, and the results are shown in Figure 1.

Based on Figure 2, there were 3 items that did not meet the criteria, i.e. the item numbers 4, 12 and 37 with INFIT MNSQ values of 1.42, 1.76 and 1.65, respectively, out of the reception area of $0.77-1.30$ or rejected. The three items were (1) I realized the weaknesses that I have when solving kinematics problems, (2) I ignored the information that is not needed in solving kinematics problems and (3) I slowed down when I find important information in solving kinematics problems. At the end, the number of analyzed items was 40.

The reliability test using SPSS obtained by Cronbach's Alpha of .90. That values showed that the reliability of metacognition instrument in solving physics problems was very good. There were no significant differences that were found between women and men based on the total score of the instrument. The women $(M=123.07, S D=13.48)$, had higher scores than men $(M=119.92, S D=14.24) t(644)=2.84, p<.001$, and Cohen's $d=.23$.

\begin{tabular}{|c|c|c|c|c|c|c|c|c|c|}
\hline Messo & .56 & .63 & .71 & .83 & 1.00 & 1.20 & 1.40 & 1.60 & 1. \\
\hline 1 item 1 & & & & & * $\quad 1$ & & & & \\
\hline $\begin{array}{l}2 \text { item } 2 \\
3 \text { item } 3\end{array}$ & & & & & & & & & \\
\hline 4 item 4 & & & & & 1 & & * & & \\
\hline $\begin{array}{l}5 \text { item } 5 \\
6 \text { item } 6\end{array}$ & & & & & & & & & \\
\hline $\begin{array}{l}0 \\
7 \text { item }\end{array}$ & & & & & $\begin{array}{r}1 \\
1 \\
1\end{array}$ & & & & \\
\hline $\begin{array}{l}8 \text { item } 8 \\
\text { item }\end{array}$ & & & & & $\vdots 1$ & & & & \\
\hline 10 item 10 & & & & & $* 1$ & & & & \\
\hline 11 item 11 & & & & & $* 1$ & & & & . \\
\hline 13 item 13 & & & & & 1 & & & & \\
\hline 14 item 14 & & & & & $\approx \quad 1$ & & & & \\
\hline 15 item 15 & & & & & * & . & & & \\
\hline $\begin{array}{l}16 \text { item } 16 \\
17 \text { item } 17\end{array}$ & & & & & 1 & & & & \\
\hline 18 item 18 & & & & & $x^{*}$ & & & & \\
\hline $\begin{array}{l}19 \text { item } 19 \\
20 \\
\text { itenm } 20\end{array}$ & & & & & $x^{*}$ & & & & \\
\hline 21 item 21 & & & & & $* i$ & & & & \\
\hline 22 item 22 & & & & & .1 & & & & \\
\hline $\begin{array}{l}23 \text { item } 23 \\
24 \text { item } 24\end{array}$ & & & & & 1 & & & & \\
\hline 25 item 25 & & & & & Ix & & & & \\
\hline $\begin{array}{l}266 \text { item } 26 \\
27 \text { item } 27\end{array}$ & & & & & 1 & & & & \\
\hline 28 item 28 & & & & & ! & & & & \\
\hline $\begin{array}{l}29 \text { item } 29 \\
30 \text { item } 30\end{array}$ & & & & & $\hat{i}$ & & & & \\
\hline 31 item 31 & & & & & 1 & & & & \\
\hline $\begin{array}{l}32 \text { item } 32 \\
33 \text { item } 33\end{array}$ & & & & & & & & & \\
\hline 34 item 34 & & & & & $* 1$ & & & & \\
\hline $\begin{array}{l}25 \text { item } 25 \\
36 \text { item } 36\end{array}$ & & & & & \pm 1 & & & & \\
\hline 37 item 37 & & & & & . 1 & & & . & \\
\hline 38 item as & & & & & & & & & \\
\hline 40 item 40 & & & & & $i$ & & & & \\
\hline 41 item 41 & & & & & I & & & & \\
\hline $\begin{array}{l}42 \\
43 \text { item } 42 \\
40 \text { item } 43\end{array}$ & & & & & $* 1$ & & & & \\
\hline
\end{tabular}

\section{Figure 2}

The plot of Metacognition Items in Solving Physics Problems

\section{The Exploratory Factor Analysis}

The inter-item correlation of the 40 items in the factor analysis determined by the Bartlet test obtained $\chi^{2}=584,10, d f=456, p<.001$, and the Kaiser Meyer Olkin measure of 
sampling adequacy (KMO) of .918 that was bigger than .50. The Guttman-Kaiser rules were shown that eigenvalues were bigger or equal to 1 and there were 9 factors was formed. At the same time, these nine factors calculated for $55.59 \%$ of the total variance. Then, the inspection was done by looking at the value of the lodging factor of each item using the varimax method. Based on the results of rotation with a maximum lodging value, there were 8 factors formed as presented in Table 2. The 9th factor in items of 7 and 20 was absorbed into the factor 1 . The eigenvalue, the variance percentage and the cumulative percentage by each factor are listed in Table 1.

Table 1

Eigenvalue, Variance Percentage, and Cumulative Percentage of Each Factor

\begin{tabular}{llll}
\hline \multirow{2}{*}{ Factor } & Initial Eigenvalues & \% of Variance & Cumulative \% \\
\cline { 2 - 4 } & Total & 23.56 & 23.56 \\
1 & 9.42 & 6.39 & 29.95 \\
2 & 2.56 & 4.45 & 34.40 \\
3 & 1.78 & 4.20 & 38.60 \\
4 & 1.68 & 3.97 & 42.56 \\
5 & 1.59 & 3.50 & 46.06 \\
6 & 1.40 & 3.46 & 49.52 \\
7 & 1.38 & 3.08 & 52.60 \\
8 & 1.23 & 3.00 & 55.59 \\
9 & 1.19 & & \\
\hline
\end{tabular}

Based on the number of contained factors, the next factor was naming. The naming of factors was based on the factor load after being rotated by taking into account the magnitude of the factor loads that more than .40 (Retnawati, 2016). The load factors that have been rotated are presented in Table 2 .

The factor of 1 was the regulation of cognition related to monitoring which contained seven items, contributing $23.5 \%$ of the total variations number among the student responses to the questionnaire items. It can be interpreted that the students were more careful in the process of solving physics problems.

The factor of 2 was the arrangement of cognition, namely information management that contained six items. These items referred to the arrangement of one's cognition through the use of information in the form of drawing, text marking, and other information needed in the process of solving physics problems. This factor explained $6.39 \%$ of the total variation among the student responses in the questionnaire items. The factor of 3 was cognition knowledge with declarative knowledge contained five items. This factor contributed for $4.45 \%$ of the total variation among the students' responses to the questionnaire items. The factor of 4 contained five items, namely the cognition settings related to debugging with $4.20 \%$ of the total variation among the students' responses to the questionnaire items. The factor of 5 consisted of five items, namely the cognition arrangement in the evaluation process with $3.97 \%$ of the total variation among the students' responses to the questionnaire items. The factor of 6 for cognition knowledge on the procedural components involved four items with $3.50 \%$ of the total variation among the students' responses to questionnaire items. The factor of 7 included four items with $3.46 \%$ of the total variation among the students' responses to questionnaire items. This item was included in the cognition settings for the planning component. The 
factor 8 was the conditional knowledge contributing to $3.08 \%$ of the total variation among the students' responses to questionnaire items.

The eight factors identified by exploratory factor analysis that were predicted as dimensions when students understood their metacognition in solving physics problems. The development of metacognition has been done by Taasoobshirazi and Farley (2013) in the form of questionnaires for students.

Table 2

Rotation Results with Maximum Loading Values

\begin{tabular}{|c|c|c|c|c|c|c|c|c|c|}
\hline \multicolumn{10}{|c|}{ Rotated Factor Matrix ${ }^{\mathrm{a}}$} \\
\hline \multirow{2}{*}{ Item } & \multicolumn{9}{|c|}{ Factor } \\
\hline & 1 & 2 & 3 & 4 & 5 & 6 & 7 & 8 & 9 \\
\hline F26 & & & .507 & & & & & & \\
\hline F32 & & & .714 & & & & & & \\
\hline F14 & & & .587 & & & & & & \\
\hline F36 & & & .581 & & & & & & \\
\hline F21 & & & .506 & & & & & & \\
\hline F41 & & & & & & 647 & & & \\
\hline F06 & & & & & & .606 & & & \\
\hline F18 & & & & & & .552 & & & \\
\hline F10 & & & & & & .520 & & & \\
\hline F38 & & & & & & & & .506 & \\
\hline F02 & & & & & & & & .505 & \\
\hline F16 & & & & & & & & .478 & \\
\hline F31 & & & & & & & & .406 & \\
\hline F25 & & & & & & & .631 & & \\
\hline F03 & & & & & & & .486 & & \\
\hline F33 & & & & & & & .482 & & \\
\hline $\mathrm{F} 22$ & & & & & & & .514 & & \\
\hline F39 & .671 & & & & & & & & \\
\hline F07 & .438 & & & & & & & & .199 \\
\hline F40 & .668 & & & & & & & & \\
\hline F13 & .490 & & & & & & & & \\
\hline $\mathrm{F} 42$ & .569 & & & & & & & & \\
\hline $\mathrm{F} 20$ & .447 & & & & & & & & .266 \\
\hline F35 & .600 & & & & & & & & \\
\hline F24 & & & & & .582 & & & & \\
\hline F15 & & & & & .425 & & & & \\
\hline F30 & & & & & .517 & & & & \\
\hline F28 & & & & & .558 & & & & \\
\hline F08 & & & & & .465 & & & & \\
\hline F43 & & & & .523 & & & & & \\
\hline F19 & & & & .624 & & & & & \\
\hline F05 & & & & .554 & & & & & \\
\hline F27 & & & & .491 & & & & & \\
\hline F11 & & & & .589 & & & & & \\
\hline F01 & & .532 & & & & & & & \\
\hline F17 & & .493 & & & & & & & \\
\hline F29 & & .579 & & & & & & & \\
\hline F09 & & .535 & & & & & & & \\
\hline F34 & & .487 & & & & & & & \\
\hline F23 & & .583 & & & & & & & \\
\hline
\end{tabular}

International Journal of Instruction, January $2020 \bullet$ Vol.13, No.1 
Rotation Method: Varimax with Kaiser Normalization.

a. Rotation converged in 7 iterations.

Table 3

Differences between the Study of Taasoobshirazi and Farley (2013) and the Current Research (Haeruddin, 2019)

\begin{tabular}{lll}
\hline Aspects & Taasoobshirazi and Farley (2013) & Haeruddin (2019) \\
\hline Method & $\begin{array}{l}\text { Not started by working on } \\
\text { physics problems }\end{array}$ & Starting with working on physics questions \\
Item number & 24 items & 43 items \\
Number of samples & 505 & 664 \\
Data analysis & Factor analysis, inter-rater, and & Expert judgment, inter-rater, Factor \\
& Cronbach Alpha & Analysis, Item Response Theory, and \\
& & Cronbach Alpha \\
\hline
\end{tabular}

Revising and developing new items is the common procedure as the construct validation process within a series of studies (Glynn et al., 2009). After the revision stage, the following step was cross-validated with the confirmatory factor analysis on a new sample of students (Taasoobshirazi et al., 2015; Glynn et al., 2009). This instrument can also be used to assess students' metacognition in solving physics problems in other materials, such as force and energy, electricity, magnetism, fluid, optics as the basic concepts for understanding advanced physics.

The direction for future research is to illustrate how the variables among the metacognition interaction by testing with structural equation models. By knowing the way of these variables affect one another and the biggest impact of the variables, it is expected that the knowledge generated from these studied variables can be complete to enhance physics teaching and learning, especially the students' problem solving skills. Moreover, the following research may also employ the qualitative approach in order to provide stronger and more comprehensive findings in the metacognition area (Abdullah, 2006).

The instrument of metacognition in this study can be applied to evaluate both the level of metacognition of high school students and college students in solving physics problems. This can also be used to determine the extent to which various methods and techniques influence students' metacognition skills in physics problem solving.

\section{CONCLUSION}

The research findings indicate that the metacognition instrument in solving physics problems has fulfilled the validity and the reliability aspects. The results of content validity showed Aiken's $V$ value of .81 , Cronbach's alpha value of .90 that can be categorized as very high, and the average value of INFIT MNSQ was $1.00 \pm .18$. The results of the factor analysis on the questionnaire also found that questionnaire items fulfilled the construct validity.

There were eight metacognition factors that were identified to be predicted as the dimensions of students' physics problem solving. These factors consist of declarative knowledge, procedural knowledge, conditional knowledge, planning, monitoring, evaluation, debugging and information management. The instrument of metacognition in 
this study can be applied to evaluate both the level of metacognition of high school students and college students in solving physics problems.

\section{RECOMMENDATIONS}

This instrument can be used to reveal students' metacognition in solving physics problems. It can be used as a pre and post scale to assess the effectiveness of such instructional that has been designed to improve students' metacognition. For the future studies, the analysis of the scale validity and reliability can be re-examined to the college students from various university departments or high school students in order to significantly increase generalizability.

\section{REFERENCES}

Abdullah, F. A. P. (2006). The patterns of physics problem-solving from the perspective of metacognition. New Hall (Murray Edwards College), Faculty of Education. Retrieved from Abdullah2006metacognition.pdf http://people.ds.cam.ac.uk/kst24/ResearchStudents/

Adams, R.J \& Kho, S.T. (1996). Quest: The interactive test analysis system version 2.1. Camberwell, Victoria: The Australian Council for Education Research.

Akyol, Z., \& Garrison, D. R. (2011). Assessing metacognition in an online community of inquiry. Internet and Higher Education, 14(3), 183-190. https://doi.org/10.1016/ j.iheduc.2011.01.005

Alexander, P. A. (2008). Why this and why now? Introduction to the special issue on metacognition, self-regulation, and self-regulated learning. Educational Psychology Review, 20(4), 369-372. https://doi.org/10.1007/s10648-008-9089-0

Allen, B. A., \& Armour-Thomas, E. (1993). Construct validation of metacognition. Journal of Psychology: Interdisciplinary and Applied, 127(2), 203-211. https://doi.org/ 10.1080/00223980.1993.9915555

Balta, N., Mason, A. J., \& Singh, C. (2016). Surveying Turkish high school and university students' attitudes and approaches to physics problem solving. Physical Review Physics Education Research, 12(1), 010129. https://doi.org/10.1103/ PhysRevPhysEducRes.12.010129

Chekwa, E., McFadden, M., Divine, A., \& Dorius, T. (2015). Metacognition: transforming the learning experience. Journal of Learning in Higher Education, 11(2), 109-112.

Colthorpe, K., Sharifirad, T., Ainscough, L., Anderson, S., \& Zimbardi, K. (2018). Prompting undergraduate students' metacognition of learning: implementing 'metalearning' assessment tasks in the biomedical sciences. Assessment \& Evaluation in Higher Education, 43(2), 272-285. https://doi.org/10.1080/02602938.2017.1334872

De Cock, M. (2012). Representation use and strategy choice in physics problem solving. Physical Review Special Topics - Physics Education Research, 8(2), 1-15. 


\section{https://doi.org/10.1103/PhysRevSTPER.8.020117}

Dinsmore, D. L., Alexander, P. A., \& Loughlin, S. M. (2008). Focusing the conceptual lens on metacognition, self-regulation, and self-regulated learning. Educational Psychology Review, 20(4), 391-409. https://doi.org/10.1007/s10648-008-9083-6

Flavell, J. H. (1979). Metacognition and cognitive monitoring: A new area of cognitivedevelopmental inquiry. American Psychologist, 34(10), 906-911. https://doi.org/ 10.1037/0003-066x.34.10.906

Flavell, J. H. (1976). Metacognitive aspects of problem solving. In L. B. Resnick (Ed.), The nature of intelligence (pp. 231-235). Hillsdale, NJ: Lawrence Erlbaum

Garrison, D. R., \& Akyol, Z. (2015). Toward the development of a metacognition construct for communities of inquiry. Internet and Higher Education, 24, 66-71. https://doi.org/10.1016/j.iheduc.2014.10.001

Ghanizadeh, A. (2017). The interplay between reflective thinking, critical thinking, selfmonitoring, and academic achievement in higher education. Higher Education, 74(1), 101-114. https://doi.org/10.1007/s10734-016-0031-y

Glynn, S. M., Taasoobshirazi, G., \& Brickman, P. (2009). Science motivation questionnaire: Construct validation with nonscience majors. Journal of Research in Science Teaching, 46(2), 127-146. https://doi.org/10.1002/tea.20267

Hair, J. F., Black. W. C., Babin. B. J., \& Anderson. R. E.. (2010). Multivariate data analysis. Pearson Prentice Hall

Hegde, B., \& Meera, B. N. (2012). How do they solve it? An insight into the learner's approach to the mechanism of physics problem solving. Physical Review Special Topics - Physics Education Research, 8(1), 1-9. https://doi.org/10.1103/PhysRevSTPER. 8.010109

Ibrahim, B., \& Rebello, N. S. (2013). Role of mental representations in problem solving: Students' approaches to nondirected tasks. Physical Review Special Topics Physics Education Research, 9(2), 1-17. https://doi.org/10.1103/PhysRevSTPER.9. 020106

Ivanjek, L., Susac, A., Planinic, M., Andrasevic, A., \& Milin-Sipus, Z. (2016). Student reasoning about graphs in different contexts. Physical Review Physics Education Research, 12(1), 010106. https://doi.org/10.1103/PhysRevPhysEducRes.12.010106

Jahangard, Z., Soltani, A., \& Alinejad, M. (2016). Exploring the relationship between metacognition and attitudes towards science of senior secondary students through a structural equation modeling analysis. J. of Baltic Science Education, 15(3), 340-349.

Koch, A. (2001). Training in metacognition and comprehension of physics texts. Science Education, 85(6), 758-768. https://doi.org/10.1002/sce.1037

Kohl, P. B., \& Finkelstein, N. D. (2008). Patterns of multipe representation use by experts and novices during physics problem solving. Physical Review Special Topics - 
Physics Education Research, 4(1), 1-13. https://doi.org/10.1103/PhysRevSTPER. 4.010111

Kryjevskaia, M., Stetzer, M. R., \& Grosz, N. (2014). Answer first: Applying the heuristic-analytic theory of reasoning to examine student intuitive thinking in the context of physics. Physical Review Special Topics - Physics Education Research, 10(2), 020109. https://doi.org/10.1103/PhysRevSTPER.10.020109

Mardapi, D. (2012). Pengukuran penilaian \& evaluasi Pendidikan. Yogyakarta: Nuha Medika.

Meijer, J., Sleegers, P., Elshout-Mohr, M., van Daalen-Kapteijns, M., Meeus, W., \& Tempelaar, D. (2013). The development of a questionnaire on metacognition for students in higher education. Educational Research, 55(1), 31-52. https://doi.org/10.1080/00131881.2013.767024

Mundilarto. (2003). Kemampuan Mahasiswa menggunakan pendekatan analitis kuantitatif dalam pemecahan soal fisika the student's ability to use quantitative analytical approach in. Jurnal Pendidikan Matematika Dan Sains, 3(VIII), 137-142.

Pintrich, P. R., Smith, D. A. F., Garcia, T., \& Mckeachie, W. J. (1993). Reliability and predictive validity of the motivated strategies for learning questionnaire (Mslq). Educational and Psychological Measurement, 53(3), 801-813. https://doi.org/10.1177/0013164493053003024

Retnawati, H. (2016). Analisis kuantitatif instrumen penelitian (Panduan Peneliti, Mahasiswa, dan Psikometrian). Yogyakarta: Parama Publishing.

Schraw, G., Crippen, K. J., \& Hartley, K. (2006). Promoting self-regulation in science education: Metacognition as part of a broader perspective on learning. Research in Science Education, 36(1-2), 111-139. https://doi.org/10.1007/s11165-005-3917-8

Schraw, G., \& Dennison, R. S. (1994). Assessing metacognitive awareness. Contemporary Educational Psychology, 19(4), 460-475. https://doi.org/10.1006/ceps.1994.1033

Sperling, R. A., Howard, B. C., Miller, L. A., \& Murphy, C. (2002). Measures of children's knowledge and regulation of cognition. Contemporary Educational Psychology, 27(1), 51-79. https://doi.org/10.1006/ceps.2001.1091

Srinivasan, D. P., \& Pushpam, M. A. M. (2016). Exploring the influence of metacognition and metaemotion strategies on the outcome of students of IX Std.. American Journal of Educational Research, 4(9), 663-668. https://doi.org/10.12691/education-4-9-3

Taasoobshirazi, G., Bailey, M., \& Farley, J. (2015). Physics metacognition inventory part II: Confirmatory factor analysis and Rasch analysis. Int. Journal of Science Education, 37(17), 2769-2786. https://doi.org/10.1080/09500693.2015. 1104425

Taasoobshirazi, G., \& Farley, J. (2013). Construct Validation of the physics 
metacognition inventory. International Journal of Science Education, 35(3), 447-459. https://doi.org/Doi 10.1080/09500693.2012.750433

Veenman, M. V. J., Van Hout-Wolters, B. H. A. M., \& Afflerbach, P. (2006). Metacognition and learning: Conceptual and methodological considerations. Metacognition and Learning, 1(1), 3-14. https://doi.org/10.1007/s11409-006-6893-0

Wall, K. (2008). Understanding metacognition through the use of pupil views templates: Pupil views of learning to learn. Thinking Skills and Creativity, 3(1), 23-33. https://doi.org/10.1016/j.tsc.2008.03.004

Walsh, L. N., Howard, R. G., \& Bowe, B. (2007). Phenomenographic study of students' problem solving approaches in physics. Physical Review Special Topics - Physics Education Research, 3(2), 1-12. https://doi.org/10.1103/PhysRevSTPER.3.020108

Zohar, A., \& Barzilai, S. (2013). A review of research on metacognition in science education: current and future directions. Studies in Science Education, 49(2), 121-169. https://doi.org/10.1080/03057267.2013.847261 